\title{
Human Resources Management Practices and Employees' Performance in Bahrain Airport Services Company
}

\author{
Maryam Mohamed AlBastaki \\ Ministry of Information, Kingdom of Bahrain. \\ E-mail: maryoom.92@ hotmail.com \\ Dr. Mohammed Youssif Abu Keir \\ Applied Science University, Kingdom of Bahrain \\ E-mail: mohammed.yousif@asu.edu.bh
}

Dr. Ahmed Mohammed Arbab

Applied Science University, Kingdom of Bahrain

E-mail: ahmed.arbab @asu.edu.bh

Received: Feb. 5, 2019 Accepted: Feb. 27, 2019 Online published: Mar. 21, 2019

doi:10.5296/ijhrs.v9i2.14318ＵRL: https://doi.org/10.5296/ijhrs.v9i2.14318

\begin{abstract}
The objective of the research is to investigate, examine and analyze the impact of human resources management practices on the performance of the employees in the Bahrain Airport Services Company (BAS). The data was collected through a questionnaire that has been designed. The questionnaire was distributed to a random sample consisting of 346 employees representing the researched community. Software package SPSS 22, was used for data analysis. Analytical and descriptive methods were employed to answer the research questions and to test the research hypotheses. The results indicated that there is a statistically significant impact of human resources management practices on the performance of the employees in the Bahrain Airport Services Company (BAS). Finally, some recommendations have been suggested.
\end{abstract}


Keywords: human resource management practices, incentives, promotions, and performance evaluation, employees' performance, Bahrain Airport Services Company (BAS)

\section{Introduction}

Employees' Performance is one of the basic criteria for judging the overall performance of organizations. Organizations' success or failure depends on the work and effort of the employees, which is equal to the expectations of the officials on the one hand, and with the level of conformity between the performance and the organization goals and vision on the other.

There is no doubt that the employees' performance and development is one of the most important practices of the human resources management, as it is the administration that is in charge to attract staff, train them, and promote them in their career path, which in turn is reflected in one way or another in the overall performance of employees.

According to Khanna and Sehgal (2016), human resource management practices focus on the optimal and effective use of employees in order to maximize performance.

The Bahrain Airport Services Company (BAS) is one of the largest governmental institutions in the Kingdom of Bahrain. It was established in 2008 to support Bahrain Airport in terms of maintenance, tourism, shipping, transport and other functions. It is one of the important service sectors that contribute significantly to the improvement of the Kingdom's interface (the company's official website http://www.bahrainairport.com)

Therefore, the current study emphasizes the need to disclose the impact of some human resources management practices, (incentives, promotions, and performance evaluation) on the performance of the employees in the Bahrain Airport Services Company (BAS).

\section{Literature Review}

\section{Human Resource Management Practices}

The modern administrative thought is concerned with human capital as the main engine of the physical capital of enterprises. Human resources management is one of the departments dealing with human capital management through its various practices and strategies. The aim of these practices is to raise the level of performance of employees so that they can perform their functions fully (Islam, Bangish, Muhammad, \& Jehan, 2016).

Business organizations rely mainly on human resources, financial resources, and technological resources. Human resources are the most important resources, as these organizations still need the human element to produce goods and provide services to clients. Therefore, the human element is very important and depends on it in these organizations (Dy Kam, 2015). In this sense, human resources are among the main pillars of organizations, because they seek to achieve their goals through their workers (Koç, Çavuş, \& Saraçoglu 2014).

Despite the importance of the financial resources of an organization, as well as the extent to 
which they use modern technology in its field of work, its success depends primarily on the efficiency, enthusiasm and effectiveness of its employees (Hosain, 2016).

Based on the above, it could be said that the research shows that the role of human resources management has an important and effective role in increasing the motivation of the employees to develop their abilities and encourage them to develop their performance professionally and knowingly. There can be no hoped results from human resource management efforts unless the employees have a genuine desire and self-motivation towards development (Omar, Arbab, \& Abdulrahman, 2018).

Human resources management practices refer to the skills, abilities, tendencies and values of employees within the organization. HRM practices are a combination of policies and practices to enhance human capital to reach the organization's goals (Arbab \& Mahdi, 2018).

It also involves the use of a comprehensive approach to the organizational development with a clear focus on the implementation of strategic change and the development of the organizational skills base to ensure that the organization is able to compete effectively in the future through some aspects such as organizational effectiveness. As well as more specific aspects such as personnel management, resources, learning and development, incentives and employee relations, as well as procedures that distinguish the company from its competitors (Luftim, 2016). These are the practices of human resources management in business organization to identify, select, train and develop the human resources working in these institutions to achieve organizational goals (Kumar, 2014).

Ruwaini (2014) defines human resource management practices as all jobs conducted by managers, such as selection, training, communication, assessment, termination procedures. The Organization's administrative body implements all human resource practices in terms of planning, job analysis, recruitment and selection of personnel, incentives and training of staff (Al Hosani, Arbab, and Elmasri 2017).

They can also be defined as a combination of policies, practices and systems that positively affect a person's behavior and direction towards his or her organization. Employees within the organization therefore consider human resources management as a management or a body committed to their rights and duties towards their work by the employer (Whitener, 2001).

Human resource management practices are therefore of great importance in the management and organization of business, as qualified personnel are a guarantee of productivity increase. In addition, good staff performance benefits both people and the organization. The more motivated employees, the more successful the organization is (Rounok \& Parvin, 2011).

The researchers see that the previous definitions of human resource management practices focused on the good use of the human resources from the beginning of employment until the end of their service. During this period, the human resources department aims at paying attention to the fact that this exploitation of human resources is focused on serving the objectives of the institution directly or indirectly. Thus, the management of human resources within the Organization is an important aspect of its advancement, since promotion, prosperity and development depend primarily on the human element in the first place (Luftim, 
2016).

Gurhan (2015) believes that the primary objective of human resources management within organizations is to work towards achieving goals and success by emphasizing the human element. AlMannai, Arbab, \& Darwish (2017) pointed out that human resources management carries out many important functions such as performance evaluation, incentives and rewards, employees' promotions according to their competence, and creating competitive environment for achieving the organization objectives efficiently and effectively.

Noe, Hollenbeck, Gerhart, and Wright (2008) have shown that human resources management decisions have an impact on employees' performance and behavior within the organization, as the primary objective is to achieve the goals set and increase production. This is achieved by encouraging continuous competition in the presence of people with knowledge and expertise. In addition, the work of this department will increase the motivation of employees to achieve the profit that the organization aspires (Danish \& Ushman, 2010; Omar et al., 2018).

\section{Incentives and Rewards}

Incentives and rewards are defined as grants in the form of material or moral word provided by an employer to employees for additional efforts made by them in their jobs or a reward for employees for their services (Akhter, Hussain, Bhatti, Shahid, \& Ullah, 2016). Arbab \& Mahdi (2018) have defined them as wages earned by individuals within the organization and he has classified them as direct wages in the form of salaries, incentives and rewards, and indirect wages in the form of leave and insurance.

Priyaka and Manu (2016) stated that incentives are all the material returns, services that individuals receive through their jobs, and aims at increasing motivation and productivity. The material return is the basic salary, incentives and rewards, while the services are insurance, pensions, and leave. He added that incentives are an organized process to increase the knowledge and skills of employees and, accordingly, they are a process aimed at changing staff behavior that will lead to achieving organizational goals.

The researchers believe that incentives and rewards are not valuable in themselves unless they are managed and well directed to make an impact on employees' minds in a way that will raise their morale towards work and achievement. Therefore, there is a need for incentives diversification into physical, moral, individual and collective, so that the institution benefits from the characteristics of each of these types.

\section{Promotions}

Promotion is the qualification of an employee that places him in a job at a higher postion than his previous one and is often accompanied by an increase in salary. It may be within the current job, and the employee may be transferred to a higher position. It is a process of continuous development depending on the duration of employment, the experience gained and the degree of proficiency (Malik, Danish, \& Munir, 2012).

Promotion is the upgrading of the career and increasing of responsibility for the employee. It also moves the employee in the career to a higher level (Priyaka \& Manu, 2016). 
Al Hosani et al. (2017) believe that promotion is earning a higher job position in the same workplace and it is accompanied by an overall improvement in the career status. Promotions also achieve individual career growth with increased responsibility accompanied by social progress.

Gurhan (2015) stated that promotion is an administrative process aimed at moving the employee from his current job to another position at a higher organizational level within the salary scale of the staff, where the incumbent has greater duties and responsibilities and the corresponding material or moral benefits.

Based on the above, the researchers define promotion as administrative procedures in which the tasks are intertwined between human resources management and the direct supervisor of the employee. The employee feels that it is their direct supervisor who decides whether or not he will be promoted and not the human resources management functions. Therefore, more activation role of human resources management is required in the process of promotion and career expansion so that employees feel that the department has a role worth attention.

\section{Performance Evaluation}

Performance evaluation is a process that evaluates employees' performance after a period and has an implicit impact on other issues within human resources management such as recruitment and selection process, interpersonal relationships, training, wages and salaries, and promotions. This process is based on briefing staff on their duties so that the assessment is commensurate with their expectations (Gurhan, 2015).

According to Islam et al., (2016), performance appraisal is a process whereby the employee is evaluated over a specific period, and helps to grow the professional career of individuals by measuring their skills and the extent of their achievements during that period. Performance evaluation is a cornerstone in drawing up development plans.

Luftim (2016) believes that performance assessment enables us to know and judge staff performance, and is primarily designed to improve performance and increase productivity. In addition, a tool measures the current employee level and indicates future performance.

Performance evaluation can be defined as a structured and formal interaction by managers, officials or supervisors usually in the form of a periodic interview (annual or semi-annual), where subordinate work is examined and discussed with a view of identifying weaknesses and strengths, as well as opportunities to improve and develop skills (Dy Kam, 2015).

Rounok \& Parvin (2011) claim that the performance evaluation process helps supervisors keep track of subordinates constantly and to motivate employees to work effectively.

Based on the above, the researchers believe that performance evaluation is an important management practice for human resources, through which the management stands at the level of performance of its staff, and knowledge of their strengths and weaknesses, which helps to draw up future development plans and strategies. As a result, there are many areas where performance evaluation outcomes can be used for different purposes such as transfer and promotion, evaluation of supervisors, wages, salaries, and bonuses determination, and 
knowledge of training needs.

Therefore, performance evaluation is critical when setting plans associated with career structure and individual promotions because the evaluation provides an opportunity for staff to identify the organization's responses to their work and development. It is therefore performance evaluation that is considered a presentation of the employees' work, their degree of mastery of their work, and the extent to which they become responsible.

\section{Employees' Performance}

Due to the importance of employees' performance, the term has received an abundance of interest from researchers and scholars both at the general level through administrative studies and at the special level through human resources studies. Given the interplay of variables that can affect employees' performance, it is the outcome of any organization's work and is of great importance as an indicator of the organization existence, (Dy Kam, 2015).

The concept has attracted the interest of researchers and writers. Studies have focused on the development of solutions to employment problems, most of which focus on involvement of staff in the development of organizational policies, reorganization of organizational structure, use of teamwork and task forces.

There are many definitions of employees' performance. Some writers and researchers see it as the behavior of individuals within the organization and some consider it as the outcome of the work of the organization. Others look at it as the ultimate outcome of an individual's efforts.

Employee' performance is defined as behavior, act or work related to the achievement of the objectives of the organization in which the employee is employed (Ilyas, Farooqi, \& Ahmad, 2016).

Jeet \& Sayeeduzzafar (2014) defines Performance as the behavior of employees within the organization to achieve their desired goals. This means that it is a summary of the achievements made by the worker within the organization according to the tasks entrusted to him. Al Shammari (2007) defines it as the implementation of the tasks entrusted to the worker, the knowledge of his duties and commitment to them, and the responsibility to achieve the objectives of the organization.

As reflected in the definitions above, the researchers believe that performance has various meanings, and it could be perceived as behavior and or achievement.

The measurement of performance includes three dimensions namely: efficiency, effectiveness and participation of the employee.

Efficiency is level of competence of an employee that could be seen in his capacity, skills, knowledge, and qualifications that enable him to carry out all his activities in more efficient ways compared to others. Technical competence is thus seen through the availability of the knowledge required for the individual to carry out the job duties (Ilyas et al., 2016).

The concept of efficiency refers to the employees' accumulated experience which enables them to accomplish their work in the least time, with minimal effort, with little error or waste, 
and with remarkable distinction (Jayatilake, 2016).

Effectiveness is defined as the degree to which an employee is able to achieve the objectives of the organization entrusted to him. In addition, it means the correct action to the extent that the goal is achieved relative to the results (Hosain, 2016).

Participation is the ability of the individual to form good working relationships, to achieve common goals, to facilitate the work of the group through their close relations with their colleagues, and support them in the organization (Hosain, 2016). Jayatilake (2016) pointed out that participation consists of the employee's personal abilities and self-abilities to communicate positively with others, to accept their ideas and opinions, to objectively present their views, and to accomplish them in a group framework and task forces.

\section{The Relationship between of Human Resource Management Practices and the Employees' Performance according to Preceding Studies}

There is a close link between human resources management practices and employees' performance, as these practices contribute to the selection of the best human resources and their employment, thus contributing to improving the overall performance of the organization (Absar, Azim, Balasundaram, \& Akhter, 2010).

Human resources management practices are the inherent guarantee for the employee's continued work and performance through the follow up on his performance and evaluation, rewarding and enhancing his performance according to this evaluation, or punishing him in the event of mistake, and through training and development in accordance with the requirements. Therefore, human resources management has an active role in training employees, raising their competencies, developing them professionally, administratively and technically, which in turn reflects on their jobs performance (Arbab, 2016).

A study conducted by Arbab \& Mahdi (2018), indicated that there is a statistically significant impact of human resources management practices on the performance of employees.

A study by Al Hosani et al. (2017) indicated that there is a statistically significant impact of information technology on improvement of human resources directorate's performance in a selected organization in the Kingdom of Bahrain.

A study by Akhter et al., (2016) showed that there was a positive correlation between job performance, supervision and incentives. It also showed that the work teams and the intention to leave did not have a significant impact on job performance.

A study by Hosain (2016) indicated that there is a positive relationship between the job analysis, accuracy of the data obtained by the employees, relationship of managers with their employees, and participation in decision-making. In addition, it indicated that there is a negative correlation between the other variables, while the study showed that incentives, bonuses and support of supervisors all have a negative impact on retention of employees. The study concluded that there is no specific reason for staff retention, but rather a set of concerted reasons. 
The studies by of (Ilyas et al., 2016; Islam et al., 2016; Jeet \& Sayeeduzzafar, 2014) found that there is a positive statistical relationship between human resources management practices and employee performance. The studies also showed that incentives and rewards have the greatest impact on staff performance.

The studies by Hanaysha \& Tahir (2016); Sattar, Khalil, \& Hassan (2015) argued that teamwork and empowerment have an effective impact on employees' performance and then came the incentives at a later stage.

A studies by Ijigu (2015); Mehta (2014) showed that there is a statistically significant relationship between human resources management practices (incentives, rewards performance development) and performance and job satisfaction. The study also showed that employees' expectations play a vital role in effective communication with supervisors.

A study by Janjua \& Gulzar (2014) study showed that all human resources have an effective impact on employees' retention, commitment, and loyalty to work.

The study by Koç et al., (2014) claimed that there is a positive statistical relationship between management practices represented by the selection of employees, incentives, bonuses, etc., and organizational commitment and performance. The results also showed the effective impact of incentives and bonuses in particular.

A study by Oyeniyi, Afolabi, and Olayanju, (2014) showed that some management practices (incentives and promotions) have an effective impact on employees' performance.

A study by Hassan, Hassan, Farooq, Khan, \& Iqbal (2013) showed that there is a correlation between the dimensions of management practices and those incentives and rewards have a significant impact on employee loyalty, satisfaction and commitment.

A study by Yaseen (2013) revealed that wages are the most important practices that have an impact on employees' performance followed by appreciation and then promotions.

A study by Javed, Rafiq, Ahmed, \& Khan (2012) showed that there is a statistically significant relationship between incentives and rewards on the one hand and employee performance and job satisfaction on the other hand. However, the appreciation was not of significant importance at the level of employees' performance, no the training.

All of the above-mentioned researchers noted that all studies show a correlation between human resources management practices and employees' performance. Some studies also agreed that incentives and rewards had a higher impact on performance, followed by performance evaluation and promotions, while some studies showed a discrepancy between the impacts of performance evaluation on employees' performance. Therefore, the researchers believe that there is an impact of human resources management practices on the employees' performance, whether this impact comes from the role that these practices play directly or through the indirect implications of these practices on the employees' performance.

\section{Problem Statement}

Many of the literature points that poor employees' performance occurs because of 
mismanagement of human resources. However, in developing countries, the extent of investigation has been very limited to the degree that requires further study (Islam et al., 2016; Yeganeh \& Su, 2008; Dy Kam, 2015). In addition, a few studies examined the impact of human resources management practices on the employees' performance in the Kingdom of Bahrain. On the other hand, some studies have indicated that there is an active role of human resources management practices on the employees' performance (Oyeniyi et al., 2014; Sattar, 2015).

To formulate the research problem, the researchers conduct an exploratory study. The results showed a low level of employees' performance. Moreover, the researchers conduct interviews with anumber of employees regarding the researched problem. Also, the results showed there is a relationship in one way or another between human resources management practices (incentives and promotions, performance evaluation) and employees' performance.This confirms the findings of Moovala (2013) which emphasize that HRM practices in Bahrain have improved over the last two decades as business organizations have recruited qualified HR staff.

Therefore, the research problem can be identified in shedding light on the gap observed by the researchers in the previous studies on the effect of human resources management practices on the employees' performance in business organizations.

\section{Research Questions}

The researchers seek to answer the following question: What is the impact of human resource management practices on the performance of the Bahrain Airport Services Company (BAS)?

\section{Research Importance}

The importance of the current research can be summarized as follows:

1. It deals with two important issues, namely human resource management practices and employees' performance.

2. The possibility of providing some recommendations that might improve human resources management practices, which in turn reflects employees' performance at the Bahrain Airport Services Company (BAS).

\section{Research Objectives}

The researcher seeks to achieve the following objectives:

1. To learn about the reality of human resources management practices at the Bahrain Airport Services Company (BAS).

2. To identify the reality of the performance of the employees in the Bahrain Airport Services Company (BAS).

3. To understand the impact of human resources management practices on the performance of the employees in the Bahrain Airport Services Company (BAS). 


\section{Research Framework}

Figure 1 represents the theoretical framework of the study.

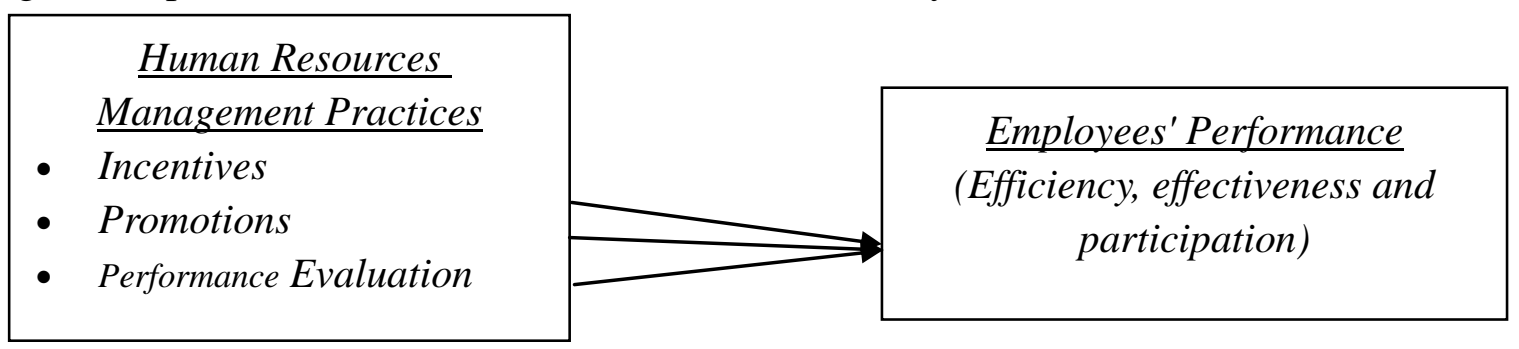

Figure 1. The theoretical model of the study

\section{Research Hypotheses}

Based on the above the researchers formulate one main hypothesis as follows:

There is a statistically significant impact of human resources management practices (incentives, promotions, performance evaluation) on the performance of the employees in the Bahrain Airport Services Company (BAS).

Sub-hypotheses are:

1. There is a statistically significant impact of incentives on the performance of the employees in the Bahrain Airport Services Company (BAS).

2. There is a statistically significant impact of promotions on the performance of the employees in the Bahrain Airport Services Company (BAS).

3. There is a statistically significant impact of performance evaluation on the performance of the employees in the Bahrain Airport Services Company (BAS).

\section{Research Method and Tool}

The current research applied the descriptive analytical approach that is based on the quantitative method. A questionnaire was designed based on the previous studies associated with the current search variables. The questionnaire aims at exploring the opinion of the employees of BAS regarding the impact of human resources management practices on the performance of the employees. The questionnaire deploys the five-point Likert scale.

\section{Research Population}

The research population includes all employees in the Bahrain Airport Services Company (BAS), from various levels (managers, departments' heads, and staff) which is 3500 individuals according to the latest statistics in 2017. This number represents the target population.

\section{Research Sample}

Based on Morgan \& Krejcie (1970), a random sample of 346 out of 3500 employees has been selected representing $10 \%$ of total target population. 346 questionnaires were distributed; the 
total return and valid questionnaires were 346 representing (100\%) of the response rate of the study sample size.

\section{Questionnaire's Validity and Reliability}

The questionnaire was presented in its initial form to a group of professors and specialists in order to express scientific opinion in the terms of the questionnaire and its dimensions. In addition, Cronbach Alpha coefficient and the correlation coefficient were calculated as shown in Table 1.

Table 1. Cronbach Alpha Coefficient and Correlation Coefficient) $n=(346)$

\begin{tabular}{llll}
\hline Questionnaire Dimensions & No. of Items & Alpha Coefficient & Correlation Coefficient \\
Incentives & 6 & 0.798 & 0.833 \\
Promotions & 6 & 0.855 & 0.834 \\
Performance Evaluation & 6 & 0.826 & 0.881 \\
Efficiency & 4 & 0.759 & 0.897 \\
Effectiveness & 4 & 0.777 & 0.725 \\
Participation & 4 & 0.821 & 0.748 \\
\hline
\end{tabular}

Table 1 indicates that the Cronbach's alpha for all variables ranged between (0.777) and (0.855). Also, it indicates that the Correlation Coefficient for all variables ranged between $(0.725)$ and $(0.897)$. Therefore, the questionnaire's validity and reliability of the measures used in this research can be considered good that allows to be used in the current study.

\section{Results Related to Research Questions}

In answering the research questions, the means, standard deviations, ranking and level are calculated for all the dimensions of the study as shown in Table 2 below.

Table 2. Means, the Standard Deviations, the Ranking and Level

\begin{tabular}{lllll}
\hline Research Dimensions & Means & Standard Deviations & Ranking & Level \\
Incentives & 3.60 & 1.11 & 6 & High \\
Promotions & 4.01 & 1.02 & 3 & High \\
Performance Evaluation & 3.77 & 1.18 & 5 & High \\
Efficiency & 4.41 & 1.19 & 1 & High \\
Effectiveness & 4.18 & 1.07 & 2 & High \\
Participation & 3.84 & 1.09 & 4 & High \\
Overall & 3.97 & 1.11 & & High \\
\hline
\end{tabular}

Table 2 indicated that all dimensions received high levels averages. It also indicated that the overall average of all research dimensions received high levels. This indicates that the elements of human resources management practices have an impact on the performance of the employee in the Bahrain Airport Services Company (BAS). 


\section{Results Related to Hypotheses Testing}

To verify the main hypothesis, a multi-linear regression analysis was performed, as illustrated in Table 3.

Table 3. Multi-Linear Regression analysis result for testing the Impact of Human Resources Management Practices on the Performance of the Employees

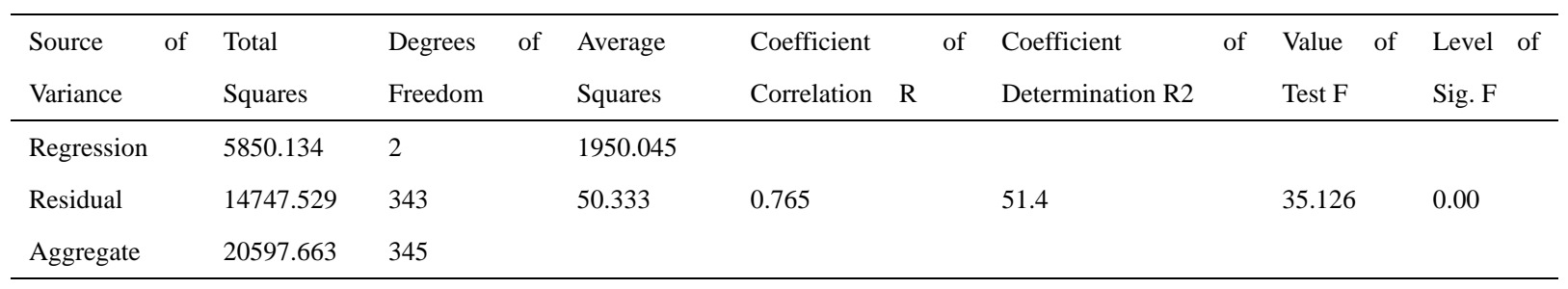

Table 3 indicates that there is a statistically significant effect of human resources management practices (incentives, promotions, performance evaluation) on the performance of the employees in the Bahrain Airport Services Company (BAS). This is due to the increase in the value of calculated $(\mathrm{F})$ which was statistically significant and reinforced by the correlation coefficient value of 0.765 . Also, it indicates that three dimensions of human resource management practices are interpreted by $51.4 \%$ of the dependent variable. Therefore, the main hypothesis is accepted. This finding is consistent with the studies of (Sattar, et al., 2015; Jeet \& Sayeeduzzafar, 2014).

To explore the impact of each dimension of human resources management practices on performance of the employees, the results were analyzed as shown in table 4.

Table 4. Results of variance analysis of multiple linear regression to test the magnitude of the impact of each dimension of Human Resources Management Practices on Performance of the Employees

\begin{tabular}{lllll}
\hline Dimension & B & $\boldsymbol{\beta}$ & T- value & Sig \\
\hline Constant & 85.325 & & 14.127 & 0.000 \\
Incentives & 0.435 & 0.090 & 6.553 & 0.004 \\
Promotions & 0.177 & 0.066 & 3.518 & 0.030 \\
Performance Evaluation & 1.332 & 0.552 & 4.707 & 0.018 \\
\hline
\end{tabular}

Table 4 indicates that most dimensions of HRM practices that have an explanation and impact on performance of the employees are incentives followed by performance evaluation and finally promotions.

To verify the sub-hypothesis 1 , a simple regression analysis was performed, as shown in Table 5. 
Table 5. Simple Regression analysis result for testing the magnitude of the effect of Incentives on the Performance of the Employees

\begin{tabular}{|c|c|c|c|c|c|}
\hline $\begin{array}{l}\text { Source of } \\
\text { Variance }\end{array}$ & $\begin{array}{l}\text { Degrees of } \\
\text { Freedom }\end{array}$ & $\begin{array}{lll}\text { Coefficient } & & \text { of } \\
\text { Correlation } & \mathbf{R} & \\
\end{array}$ & $\begin{array}{ll}\text { Coefficient } & \text { of } \\
\text { Determination R2 }\end{array}$ & $\begin{array}{ll}\text { Value } & \text { of } \\
\text { Test } \mathbf{F} & \\
\end{array}$ & $\begin{array}{ll}\text { Level of } \\
\text { Sig. F }\end{array}$ \\
\hline $\begin{array}{l}\text { Between } \\
\text { Groups }\end{array}$ & 1 & \multirow[t]{3}{*}{0.812} & \multirow[t]{3}{*}{$35.7 \%$} & \multirow[t]{3}{*}{28.972} & \multirow[t]{3}{*}{0.01} \\
\hline Within Groups & 345 & & & & \\
\hline Aggregate & 346 & & & & \\
\hline
\end{tabular}

Table 5 indicates that there is a statistically significant effect of incentives on the performance of the employees in the Bahrain Airport Services Company (BAS). This is due to the increase in the value of calculated (F) (28.972) which is statistically significant (0.01) and less than (0.05) level of significance. Also, reinforce by the coefficient of Determination R2 value of $35.7 \%$. In addition, it indicates that incentives is interpreted by $35.7 \%$ of the dependent variable. This is confirmed by the value of correlation coefficient $(0.812)$ which is a high correlation coefficient and is statistically significant.

To verify the statistical significance of the incentives effect on the performance of the employees, Beta Coefficient was performed, as illustrated in Table 6.

Table 6. Results of Beta Coefficient to verify the statistical significance of the incentives effect on the performance of the employees

\begin{tabular}{l|l|l|l|l}
\hline Dimension & B & $\boldsymbol{\beta}$ & T- value & Sig \\
\hline Constant & 35.89 & & 14.312 & 0.01 \\
\hline Incentives & 0.921 & 0.665 & 10.190 & 0.01 \\
\hline
\end{tabular}

Table 6 indicates that the value of Beta $(\beta)(0.665)$ which is also statistically significant at the level of (0.01). This means that the more the company in general and human resources management in particular implement a system of incentives that is characterized by objectivity and justice the more it has led to an increase in the performance level of the employees, as confirmed by the value of Beta $(\beta)(0.665)$. Therefore, sub-hypothesis 1 is accepted. This finding is consistent with the studies of (Akhter et al., 2016; Hosain, 2016; Ilyas et al., 2016; Islam et al., 2016; Khanna \& Sehgal., 2016; Ijigu, 2015; Jeet \& Sayeeduzzafar, 2014; Koç et al., 2014; Mehta, 2014).

To verify the sub-hypothesis 2 , a simple regression analysis was performed, as shown in Table 7.

Table 7. Simple Regression analysis result for testing the magnitude of the effect of Promotions on the Performance of the Employees

\begin{tabular}{|c|c|c|c|c|c|}
\hline $\begin{array}{l}\text { Source } \\
\text { Variance }\end{array}$ & $\begin{array}{l}\text { Degrees of } \\
\text { Freedom }\end{array}$ & $\begin{array}{l}\text { Coefficient of Correlation } \\
\mathbf{R}\end{array}$ & $\begin{array}{l}\text { Coefficient of Determination } \\
\text { R2 }\end{array}$ & $\begin{array}{l}\text { Value of Test } \\
\mathrm{F}\end{array}$ & $\begin{array}{l}\text { Level of Sig. } \\
\text { F }\end{array}$ \\
\hline Between Groups & 1 & \multirow{3}{*}{0.431} & \multirow{3}{*}{$8.9 \%$} & \multirow{3}{*}{8.324} & \multirow{3}{*}{0.05} \\
\hline Within Groups & 345 & & & & \\
\hline Aggregate & 346 & & & & \\
\hline
\end{tabular}


Table 7 indicated that there is a weak effect of promotions on the performance of the employees in the Bahrain Airport Services Company (BAS). This is due to the increase in the value of calculated $(F)$ (8.324) which was statistically significant (0.05) and high than $(0.01)$ level of significant. Also reinforce by the coefficient of Determination R2 value of $8.9 \%$. In addition, it indicated that promotions is interpreted by $8.9 \%$ of the dependent variable. This is confirmed by the value of correlation coefficient $(0.431)$ which is a weak correlation coefficient and is statistically significant.

To verify the statistical significance of the promotions effect on the performance of the employees, Beta Coefficient was performed, as illustrated in Table 8.

Table 8. Results of Beta Coefficient to verify the statistical significance of the promotions effect on the performance of the employees

\begin{tabular}{l|l|l|l|l}
\hline Dimension & B & $\boldsymbol{\beta}$ & T- value & Sig \\
\hline Constant & 25.34 & & 16.65 & 0.01 \\
\hline Promotions & 0.569 & 0.445 & 5.554 & 0.05 \\
\hline
\end{tabular}

Table 8 indicated that the value of Beta $(\beta)(0.665)$ which is also statistically significant at the level of (0.01). This means the performance of the employees of the company is not significantly related to the promotion they receive, as confirmed by the value of Beta $\beta$, (0.445), which is also a statistical value at the level.(0.05), Therefore, sub-hypothesis 2 is accepted. This finding is consistent with the studies of (Hosain, 2016; Oyeniyi et al., 2014; Yaseen, 2013).

To verify the sub-hypothesis 3, a simple regression analysis was performed, as shown in Table 9.

Table 9. Simple Regression analysis result for testing the magnitude of the effect of Performance Evaluation on the Performance of the Employees

\begin{tabular}{l|l|l|l|l|l|l}
\hline Source of Variance & $\begin{array}{l}\text { Degrees of } \\
\text { Freedom }\end{array}$ & $\begin{array}{l}\text { Coefficient of } \\
\text { Correlation }\end{array}$ & $\begin{array}{l}\text { Coefficient of } \\
\text { Determination R2 }\end{array}$ & $\begin{array}{l}\text { Value of } \\
\text { Test F }\end{array}$ & Level of Sig. F \\
\cline { 1 - 2 } Between Groups & 1 & \multirow{2}{*}{0.709} & $20.6 \%$ & 24.221 & 0.01 \\
\cline { 1 - 2 } Within Groups & 345 & & & & \\
\cline { 1 - 5 } Aggregate & 346 & & & & \\
\hline
\end{tabular}

Table 9 indicated that there is a statistically significant effect of performance evaluation on the performance of the employees in the Bahrain Airport Services Company (BAS). This is due to the increase in the value of calculated (F) (24.221) which was statistically significant (0.01) and less than (0.05) level of significant. It is Also, reinforce by the coefficient of Determination R2 value of $20.6 \%$. In addition, it indicated that performance evaluation is interpreted by $20.6 \%$ of the dependent variable. This is confirmed by the value of correlation coefficient $(0.709)$ which is a high correlation coefficient and is statistically significant.

To verify the statistical significance of the performance evaluation effect on the performance of the employees, Beta Coefficient was performed, as illustrated in Table 10. 
Table 10. Results of Beta Coefficient to verify the statistical significance of the performance evaluation effect on the performance of the employees

\begin{tabular}{l|l|l|l|l}
\hline Dimension & B & $\boldsymbol{\beta}$ & T- value & Sig \\
\hline Constant & 35.89 & & 12.277 & 0.01 \\
\hline Performance Evaluation & 0.761 & 0.599 & 8.443 & 0.01 \\
\hline
\end{tabular}

Table 10 indicated that the value of Beta $(\beta)(0.599)$ which is also statistically significant at the level of (0.01). This means that the more the company in general and human resources management in particular implement a good system of performance evaluation the more it leads to an increase in the performance level of the employees, as confirmed by the value of Beta ( $\beta$ ) (0.599). Therefore, sub-hypothesis 3 is accepted. This finding is consistent with the studies of (Hanaysha \& Tahir, 2016; Sattar, et al., 2015).

\section{Discussion}

The purpose of the research is to investigate, examine and analyze the impact of human resources management practices on the performance of the employees in the Bahrain Airport Services Company (BAS). The data was collected through a questionnaire that has been designed. The questionnaire was distributed to a random sample consisting of 346 employees representing the researched community. Analytical and descriptive methods were employed to answer the research questions and to test the research hypotheses. The results indicated that there is a statistically significant impact of human resources management practices on the performance of the employees in the Bahrain Airport Services Company (BAS), where incentives have the highest effect followed by performance evaluation, while promotions have the weak effect compared to other human resources management practices. The findings show that the company management is interested in the staff proposals regarding incentives and rewards system. Further, the findings revealed that the promotions process is not characterized by flexibility or development in an acceptable manner. Moreover, it indicated the company's performance appraisal system is fair and impartial, clear and transparent. In addition, the results revealed that the most important and highest dimensions of the performance of the employees was efficiency, followed by participation, and then effectiveness.

Overall, this study provides explanations of employees' views about the impact of human resources management practices on the performance of the employees in the Bahrain Airport Services Company (BAS). We would argue that there is a need for designing a system for career promotion and administrative escalation that is flexible, adaptable and developmental. In addition to empowering staff as preparatory steps for the promotion process. We would suggest activating the staff proposals regarding the system of incentives and bonuses in order to increase the level of satisfaction since it stems from their views so as not to feel that they are imposed on them through administrative order. In addition to creating a work environment that allows the formation of relationships between employees and helping them to increase their functional effectiveness. Moreover, to following up the modernization and development of information systems to help employees improve their performance and functions. 


\section{Conclusion}

The study is conducted in the Bahrain Airport Services Company (BAS) and examined the impact of human resources management practices (incentives, promotions, performance evaluation) on the performance of the employees.

The findings revealed that the dimensions of the human resources management practices (incentives, promotions, performance evaluation) have significant impact on the performance of the employees in the Bahrain Airport Services Company. Therefore, the findings confirm the hypotheses.

Thus, the paper adds to literature and bridges the gap between theory and practice in pinpointing new empirical evidence on human resources management practices and the performance of the employees.

The study has implications for both the public and private sectors' organizations in the Kingdom of Bahrain. The study also benefits academics, managers, consultants and practitioners in terms of educating, providing support, and raising awareness on the impact of human resources management practices (incentives, promotions, performance evaluation) on the performance of the employees in the Kingdom of Bahrain, and in countries that have similar features to those of Kingdom of Bahrain such as the Gulf countries.

This paper has the some limitations. For data collection, only questionnaire was used. In future studies mix methods for data collection could be used. In addition, sampling results may not conform to the total population results. Therefore, the results cannot be generalized to all public and private organizations

The current study looked into the significant impact of human resources management practices (incentives, promotions, performance evaluation) on the performance of the employees in the Bahrain Airport Services Company (BAS). It focused only on three dimensions of human resources management practices namely: incentives, promotions, performance evaluation. Therefore, the researchers recommend investigating other dimensions of human resources management practices such as work force planning, recruitment and selection, staffing, wages and salaries administration, training and development, talent management, etc.

\section{References}

Absar, M., Azim, M., Balasundaram, N., \& Akhter, S. (2010). Impact of Human Resources Practices on Job Satisfaction: Evidence from Manufacturing Firms in Bangladesh. Economic Sciences Series, 31-42.

Akhter, N., Hussain, A., Bhatti, M., Shahid, F., \& Ullah, H. (2016). Impact of HR Practices on Job Satisfaction: A Study on Teachers of Private and Public Sector. International Review of Management and Business Research, 5(2), 572-584.

Al Hosani, A. R., Arbab, A. M., \& Elmasri, A. A. (2017). Does Information Technology Affect Improvement of Human Resources Directorate's Performance in a Selected Organization in the Kingdom of Bahrain?. International Business and Management, 15(1), 
1-7. http://dx.doi.org/10.3968/9750.

Al Shammari, M. (2007). Performance Evaluation of Female Workers in the Security Services: An Applied Study on Passport Administration in Riyadh City (Master's thesis, Naif Arab University for Security Sciences, Riyadh).

AlMannai, A. W., Arbab, A. M., \& Darwish, S. (2017). The Impact of Talent Management Strategies on Enhancement of Competitive Advantage in Bahrain Post. International Journal of Core Engineering \& Management, 4(6), 1-17. Retrieved from: https://ijcem.in/archive.

Arbab, A. (2016). Impact of Comprehensive Quality Efficiency on Training Programs in Sudanese Universities. European Journal of Business and Management, 8(18), 193-199. Retrieved from: www.iiste.org.

Arbab, A. M., \& Mahdi, M. O. S. (2018). Human Resources Practices and organizational Excellence in Public Organizations. Polish Journal of Management Studies, 18(2), 9-21. https://doi.org/10.17512/pjms.2018.18.2.01

Bahrain Airport Services Company website. Available: http://www.bahrainairport.com.

Danish, R., \& Ushman, A. (2010). Impact of Reward and Recognition on Job Satisfaction and Motivation: An Empirical Study from Pakistan. International Journal of Business and Management, 5(2), 159-167. https://doi.org/10.5539/ijbm.v5n2p159

Dy Kam, F. (2015). The Relationship of Job Satisfaction and Employee Performance of Selected Financial Institutions in the Kingdom of Bahrain. International Advanced Research Journal in Science, Engineering and Technology, 2(1), 1-13.

Gurhan U. (2015). Stages, Content, and Theory of Strategic Human Resource Management: An Exploratory Study. Journal of Modern Accounting and Auditing, 10(2), 252-256.

Hanaysha, J., \& Tahir, P. (2016). Examining the Effects of Employee Empowerment, Teamwork, and Employee Training on Job Satisfaction. Procedia-Social and Behavioral Science, pp, 272-282. https://doi.org/10.1016/j.sbspro.2016.05.016

Hassan, M., Hassan, S., Farooq, M., Khan, A., \& Iqbal, A. (2013). Impact of HR Practices on Employee Satisfaction and Employee Loyalty: An Empirical Study of Government Owned Public Sector Banks of Pakistan. Total Quality Management, 16(1), 01-08.

Hosain, S. (2016). Impact of Best HRM Practices on Retaining the Best Employees: A Study on Selected Bangladeshi Firms. Asian Journal of Social Sciences and Management Studies, 3(2), 108-114. https://doi.org/10.20448/journal.500/2016.3.2/500.2.108.114

Ijigu, A. (2015). The Effect of Selected Human Resource Management Practices on Employees' Job Satisfaction in Ethiopian Public Banks. EMAJ: Emerging Markets Journal, 5(1), 1-16. https://doi.org/10.5195/EMAJ.2015.64

Ilyas, W., Farooqi, Y., \& Ahmad, M. (2016). Effect of Human Resource Management Practices on Employee Performance: A Study of Telecom Sector. Journal of Resources Development and Management, 20, 61-71.

Islam, Z., Bangish, S., Muhammad, H., \& Jehan, A. (2016). The Impact of HR Practices on Job satisfaction: A Case Study of Hotel Industry in Pakistan. Journal of Asian Finance, Economics and Business, 3(1), 43-48. https://doi.org/10.13106/jafeb.2016.vol3.no1.43. 
Janjua, B., \& Gulzar, A. (2014). The Impact of Human Resource Practices on Employee Commitment and Employee Retention in Telecom Sector of Pakistan: Exploring the Mediating Role of Employee Loyalty. Journal of Business and Management (IOSR-JBM), 16(1), 76-81. https://doi.org/10.9790/487X-16167681

Javed, M., Rafiq, M., Ahmed, M., \& Khan, M. (2012). Impact of HR Practices on Employee Job Satisfaction in Public Sector Organizations of Pakistan. Interdisciplinary Journal of Contemporary Research in Business, 4(1), 348-363.

Jayatilake, L. (2016). The Impact of Human Resource Practices among Academic Staff on Work Performance through Job Satisfaction: The Case of State Universities in Sri Lanka. Proceedings of 84th IIER International Conference, Kuala Lumpur, Malaysia, 17th -18th, 7-11.

Jeet, V., \& Sayeeduzzafar (2014). A Study of HRM Practices and its Impact on Employees Job Satisfaction in Private Sector Banks: A Case Study of HDFC Bank. International Journal of Advance Research in Computer Science and Management Studies, 2(1), 62-68.

Khanna, P., \& Sehgal, M. (2016). A Study of HRM Practices and its Effect on Employees Job Satisfaction in Private Sector Banks with Special Reference to ICICI Banks in Ludhiana. International Journal of Management, 4(7), 36-43.

Koç, M., Çavuş, M., \& Saraçoglu, T. (2014). Human Resource Management Practices, Job Satisfaction and Organizational Commitment. International Journal of Academic Research in Business and Social Sciences, 4(9), 178-190.

Kumar, G., \& Seemarani. (2015). A Study of Retention Variables Influencing Employee Attrition for IT-Units: With Special Reference to Pune City. International Journal in Management and Social Science, 3(2), 1064-1076.

Luftim, C. (2016). The Impact of Strategic Human Resource Management on Organizational Performance. Seria Management, 17(2), 374-383.

Malik, M., Danish, R., \& Munir, Y. (2012). The Impact of Pay and Promotion on Job Satisfaction: Evidence from Higher Education Institutes of Pakistan. American Journal of Economics, Special Issue: 6-9. https://doi.org/10.5923/j.economics.20120001.02

Mehta, A. (2014). A Review and Research Agenda; Impact of Human Resource Practices on Job Satisfaction of Employees in Foreign and Local Banks of Pakistan. Journal of Human Resources Management and Labor Studies, 2(2), 149-158.

Moovala, V. (2013). Human Resources Practices in Banks incorporated in the Kingdom of Bahrain. Journal of Management Policies and Practices, 2(3), 97-112.

Noe, R., Hollenbeck, J., Gerhart, B., \& Wright, P. (2008). Human Resource Management: Gaining a Competitive Advantage. New York: McGraw-Hill.

Omar, K. M, Arbab, A. M., \& Abdulrahman, K. M. (2018). Motivation Effect on Human Resource Management Performance in Bahraini Market Regulatory Authority. Human Resource Management Research, 8(2), 34-41. http://dx.doi.org/10.5923/j.hrmr.20180802.02

Oyeniyi, K., Afolabi, M., \& Olayanju, M. (2014). Effect of Human Resource Management Practices on Job Satisfaction: An Empirical Investigation of Nigeria Banks. International Journal of Academic Research in Business and Social Sciences, 4(8), 243-251. 


\section{Macrothink}

International Journal of Human Resource Studies

ISSN 2162-3058 2019, Vol. 9, No. 2

Priyaka, K., \& Manu, S. (2016). A Study of HRM Practices and its effect on Employees Job Satisfaction in Private Sector Banks with Special Reference to ICICI Banks in Ludhiana. IPASJ International Journal of Management, 4(7).

Rounok, N., \& Parvin, M. (2011). Fostering Employee Performance: A Literature Review. Industrial Engineering Letters, 1(3), 1-10.

Ruwaini, E. S. (2014). The Role of Human Resources Information Systems in increasing the Effectiveness of Human Resource Management Performance: Field Study in the Ministry of Interior in the Kingdom of Bahrain. (Master's thesis, Applied Science University, Kingdom of Bahrain).

Sattar, T., Khalil, A., \& Hassan, M. (2015).Role of Human Resource Practices in Employee Performance and Job Satisfaction with Mediating Effect of Employee Engagement. Pakistan Economic and Social Review, 53(1).

Whitener, E. (2001). Do high commitment human resource practices affect employee commitment? A cross-level analysis using hierarchical linear modeling. Journal of Management, 27(5), 515-35. https://doi.org/10.1016/S0149-2063(01)00106-4

Yaseen, A. (2013). Effect of Compensation Factors on Employee Satisfaction- A Study of Doctor's Dissatisfaction in Punjab. International Journal of Human Resource Studies, 3(1), 142-157. https://doi.org/10.5296/ijhrs.v3i1.3351

Yeganeh, H., \& Su, Z. (2008). An Examination of human resource management practices in Iranian public sector. Personnel Review, 37(2), 203-221. https://doi.org/10.1108/00483480810850542

\section{Copyright Disclaimer}

Copyright for this article is retained by the author(s), with first publication rights granted to the journal.

This is an open-access article distributed under the terms and conditions of the Creative Commons Attribution license (http://creativecommons.org/licenses/by/4.0/). 